\title{
New Orleans: A Model 21st Century Cross-American Water City?
}

DEREK HOEFERLIN

Washington University in St. Louis

Much has been accomplished - and much debated - since Hurricane Katrina made landfall outside of New Orleans in 2005. There have been many successes - and many failures - in regards to the recovery, rebuilding and resiliency of the unique "Cross-American" port city. Social, economic and environmental justice issues have been brought to the forefront, in the wake of an unprecedented human-altered "natural" disaster. This paper will not attempt to regurgitate what has been critiqued and promulgated about New Orleans in relation to status quo rebuilding. Rather, the paper will focus on water management demands, efforts and proposals since the storm; and, how these water-centric efforts have challenged existing decision-making regimes, in turn advocating for new governance partnerships, funding streams and integrative design methodologies.

\section{INTRODUCTION}

The paper will highlight three innovative initiatives advocating for water management in the deltaic city: Dutch Dialogues, Gutter to Gulf, and the Greater New Orleans Urban Water Plan. All three advocate for similar results: the designing of innovative, multiscaled urban initiatives with new complimentary governance structures, both publicly and privately supported, that partner with design. Each advocates for a paradigm shift of how citizens live with water, over the long-term, cognizant of a tenuous relationship within a disappearing deltaic context.

It also is worth noting that there are now several water management efforts in the New Orleans region, in addition to Dutch Dialogues, Gutter to Gulf and the GNO Water Plan. These efforts range in scale, program and venue, from the lot/house scale with rain barrels, raingardens and bio-swales; to neighborhood clustering proposals with retention areas; to district level street networks with "floating streets;" to citywide passive circulating systems supplemented with existing "pipe-and-pump" regimes; and, to 100 -year coastal restoration visions engaged with contrarian interest groups. Out of necessity, the efforts oftentimes blur distinctions between academic and professional agendas, prioritizing entrepreneurial efforts in the absence of political will and funding streams. Innovative efforts include, but are not limited to: Ripple Effect (non-profit partnering with the city and Waggonner \& Ball Architects, developing a water literacy certificate for New Orleans public school students); Greater New Orleans Water Collaborative (network facilitating water management technologies, public policy, funding opportunities, partnerships); Propeller (non-profit incubator to launch social and environmental ventures), Public Lab (D.I.Y. citizen-science with a focus on environmental and social justice); among others, such as the Environmental Defense Fund/Van Alen Institute sponsored Changing Course: Navigating the Future of the Lower Mississippi River Delta international design competition; Tulane City Center; Louisiana State University Coastal Sustainability Studio; and, Groundwork New Orleans.

First, the paper will describe the regional forces that warrant the need for integrated urban water management within the City of New Orleans. Second, the paper will highlight three of these water management advocacy efforts that ultimately position New Orleans as a future "Cross-American" Water City:

\section{1) Dutch Dialogues}

2) Gutter to Gulf: Legible Water Infrastructure for New Orleans

3) Greater New Orleans Urban Water Plan

All three efforts emerged due to the complexities and issues that have arisen in New Orleans since 2005, specifically post-Hurricane Katrina, and particularly in relation to water management. It is also important to state that the author of this paper has possessed a central role in all three of these efforts. But this paper is not meant to highlight the author's role in these efforts, but rather the efforts themselves, all of which are multi-disciplinary, collaborative, and with no "single voice or author."

\section{BACKGROUND: THREE CONTEXTS FOR THE THREE INITIATIVES}

Much has been written about New Orleans post-Katrina, so it is not needed to go into serious depth about these issues. However, before presenting the three initiatives, it is important to cite 


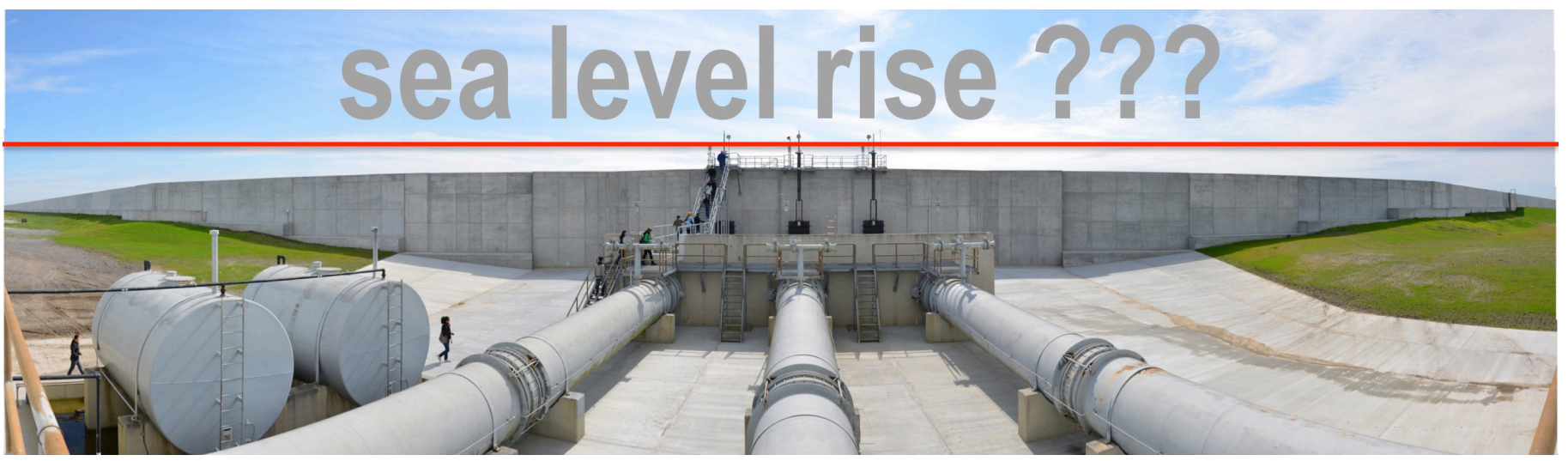

Figure 1: "The Great Wall of Louisiana," Hurricane \& Storm Damage Risk Reduction System (HSDRSS), St. Bernard Parish, Louisiana, US Army Corps of Engineers (photo credit: Derek Hoeferlin, 2012).

three particular large-scale issues directly impacting the New Orleans region, in order to frame the need for the integrated water management:

1) New Orleans as a Global Port City

2) New Orleans and Coastal Wetland Loss

3) New Orleans Status of Post-Katrina Reconstruction and Planning

1) New Orleans as a Global Port City

Casting a net in relation to the ACSA conference theme "CrossAmerica's," the delta urbanism of New Orleans indeed finds itself at a critical crossroads for 21 st century trade and commerce, more specifically in relation to competitive global, ocean-going trade. New Orleans was colonized by the French specifically for its strategic location along the Mississippi River, as the gateway to the North American continent. This strategic importance is still paramount, especially in terms of massive agricultural exports from the United State's Midwest states. Important to note is export. While many other United States ports predominantly import goods, the Mississippi watershed and its ports of New Orleans are large exporters. However, there are uncertainties about the long-term sustainability of the barge/river industry along the Mississippi River, in relation to other competitive infrastructures of rail and road. Saying that, if the port of New Orleans - and the Mississippi river and its watershed - are to remain globally competitive, the United States and ports of the New Orleans region need to come to terms with the recently completed Panama Canal expansion (June 2016). With this expansion, the canal now can accommodate post-Panamex draft-depth vessels. In other words, despite the USACE dredging regimes, the current draft depth capabilities of the Mississippi River and ports of New Orleans are not deep enough to accommodate the new draft depths that the Panama Canal expansion will allow. Other ports in the region and nation are grappling with the same issue, hence a regional and national competitiveness to accommodate such draft depth.
2) New Orleans and Coastal Wetland Loss

Due to a complex web of issues, the Louisiana coast is rapidly degrading. This is disconcerting for many environmental reasons, and also for lack of storm surge protection for the New Orleans region and Louisiana coastal communities. Overly simplistically, four human-altered factors to the built environment contribute to wetland loss as follows: 1) Sea level rise with correlating saltwater intrusion erodes the diverse estuarine gradient, particularly fresh water marshes, causing subsidence (the sinking of land); 2) A vast network of oil/gas and navigation canals, that crisscross throughout the Louisiana delta, allow for rapid saltwater intrusion; 3) the relentless leveeing of the Mississippi River for navigation, flood protection and development eliminates the ability of the river to flood seasonally. Historically, the flooding of the Mississippi River deposited sediment close to the river. This sediment provided the source to grow protective wetlands. So there is an extreme lack of fresh water supply to keep up with the sea level rise and increased saline levels. What is left of the sediment (much of the sediment is trapped in up-river dams) is forced off the continental shelf into the Gulf of Mexico; and, 4) Environmental catastrophes such as the 2005 Hurricane Katrina and the 2010 BP Oil Spill greatly accelerate the effects of coastal wetland loss. Then too, add in all of the competing human interests, this becomes a Gordian Knot for sure.

3) New Orleans Region Status of Post-Katrina Reconstruction and Planning

Another very complex issue is the recovery and long-term planning for the future resiliency and sustainability of the New Orleans region. Specifically related to water management, there are two metrics and regimes that must be considered to have the following initiatives underpinned by any form of reality: 1 ) the US Army Corps of Engineers (USACE) Hurricane \& Storm Damage Risk Reduction System (HSDRSS); and, 2) "Louisiana's Coastal Master Plan for a Sustainable Coast," by the Coastal Protection and Restoration Authority (CPRA).

Authorized by US Congress after Hurricanes Katrina and Rita, the USACE constructed the HSDRSS. At an estimated cost of \$14.5 billion USD, it consists of levees, floodwalls, gate structures and pump stations that either have been upgraded, reconstructed, or built anew. This effort was completed in 2013 and protects the 


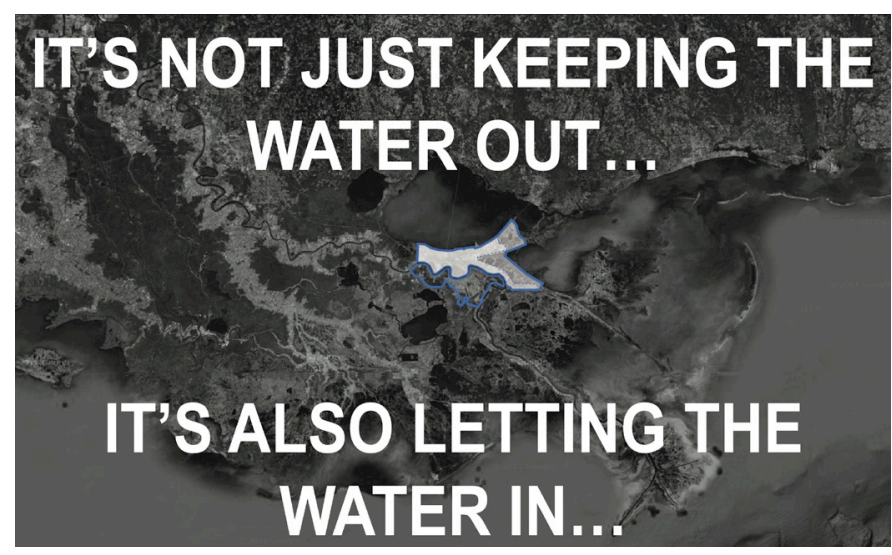

Figure 2: City of New Orleans as fortified island, wetlands separated by HSRDSS (image credit: Waggonner \& Ball Architects/Derek Hoeferlin).

New Orleans regions to a 100 -year protection level (1\% chance in one year of storm occurring). In other words, the USACE built a 131-mile wall around New Orleans. New Orleans is now "fortified," but also now an island, in-to-of-itself, cut off ecologically and experientially from its surroundings.

Prior to Hurricane Katrina, the State of Louisiana embarked on an ambitious Coastal Master Plan to address such issues of coastal wetland loss. Then Hurricane Katrina struck, and accelerated the urgency to revise the plan, in an post-disaster context. Completed in 2012, the ambitious plan outlines a suite of integrated projects to be executed over different scales and timeframes. Currently, the master plan is being updated once again, set for 2017 release, to include important, and more recent metrics for sea level rise, along with recommendations for coastal restoration projects based on river diversion proposals form the Changing Course design competition. Also, the master plan revision has been influenced by the BP Oil Spill settlement money as well, as this settlement will impact greatly the implementation of the plan.

\section{DUTCH DIALOGUES, GUTTER TO GULF, GREATER NEW ORLEANS WATER PLAN}

As stated above, there has been much attention, planning and money spent on protecting the New Orleans region with a rebuilt perimeter levee system (the HSDRSS), and the large-scale, long-term Coastal Master Plan. Also there has been a tremendous amount of rebuilding within the City of New Orleans since Hurricane Katrina. But most of this reconstruction and impressive amount of new development, other than a few cases, have been accomplished with very little understanding or appreciation of issues of integrated water management. In other words, contrary to what many believe, issues of water management in New Orleans are not just relegated to keeping water OUTSIDE of the city confines, but rather, also about letting water back INSIDE the city confines. This may sound completely counter intuitive at first, but the definition of a delta landscape can only survive if it is consistently replenished with fresh water, aka a soggy landscape. In an exact opposite sense, the New Orleans built environment is engineered to remain dry by keeping water hidden below streets in giant culverts and to be pumped out quickly. These methods keep water at bay, outside of the city - and therefore mostly absent from its soil - this causes big problems, especially in relation to issues of subsidence. Simply put, if you remove water out of the delta soil composition, gaps are exposed within the weaker portions of the organic soils, making the stronger, heavier soil types of sand, silt and clay to compress the organic soils. Hence, you have a sinking city, and one that will continue to sink unless water is reintroduced in spatially innovative methods, to create both security and amenity. If not, the sea levels rise and only a perimeter, concrete wall separates a sinking city from the rising sea.

But in addition to 20th century engineering and ecological reasons for a sinking city, there were additional complicated social and political reasons that water was conspicuously absent, particularly during the Post-Katrina recovery process. One was lack of political leadership. Another was lack of funding. And another was lack of innovative thinking during a post-disaster context. But in addition to these lacks, many residents were very nervous about the idea of areas of the city being devoted to water. Rightfully so, many residents had been betrayed by both the false protection of the US Army Corps of Engineers levee system, but also had been deceived in the past by powerful forces that would do such sinister things like dynamite levees and flood areas of poorer parts of the city to save richer parts of the city. American, Southern, and New Orleans history was not on their side.

So during these challenging post-Katrina years, two interrelated water management initiatives-Dutch Dialogues and Gutter to Gulf: Legible Water Infrastructure for New Orleans-began to take root, and took years to enact. Both addressed the severe issue of a sinking city, one starving from the lack of water. Both started with a foundational understanding of the landscape of New Orleans, rooted in water. Both began in 2008, and at the time, were the only two water management advocacy efforts that focused on multiple, ecological scales of integrated water systems, within the City of New Orleans.

Dutch Dialogues:

1) Is a citizen-led grassroots effort, spearheaded by local architect David Waggonner and his firm Waggonner \& Ball Architects, with support from the Royal Netherlands Embassy, Washington D.C. and the American Planning Association

2) Promotes a unique multi-disciplinary workshop methodology that brought together Dutch experts and their local/regional counterparts to study the city's dilemmas of water management, at multiple scales and in multiple neighborhoods, across the city and region

3) Due to its affiliation with the Dutch Embassy, has a unique form of political teeth, without being directly tied to any political agenda in New Orleans itself. In the world of Louisiana politics, that is a rare mixture. Therefore, Dutch Dialogues had relative autonomy and 


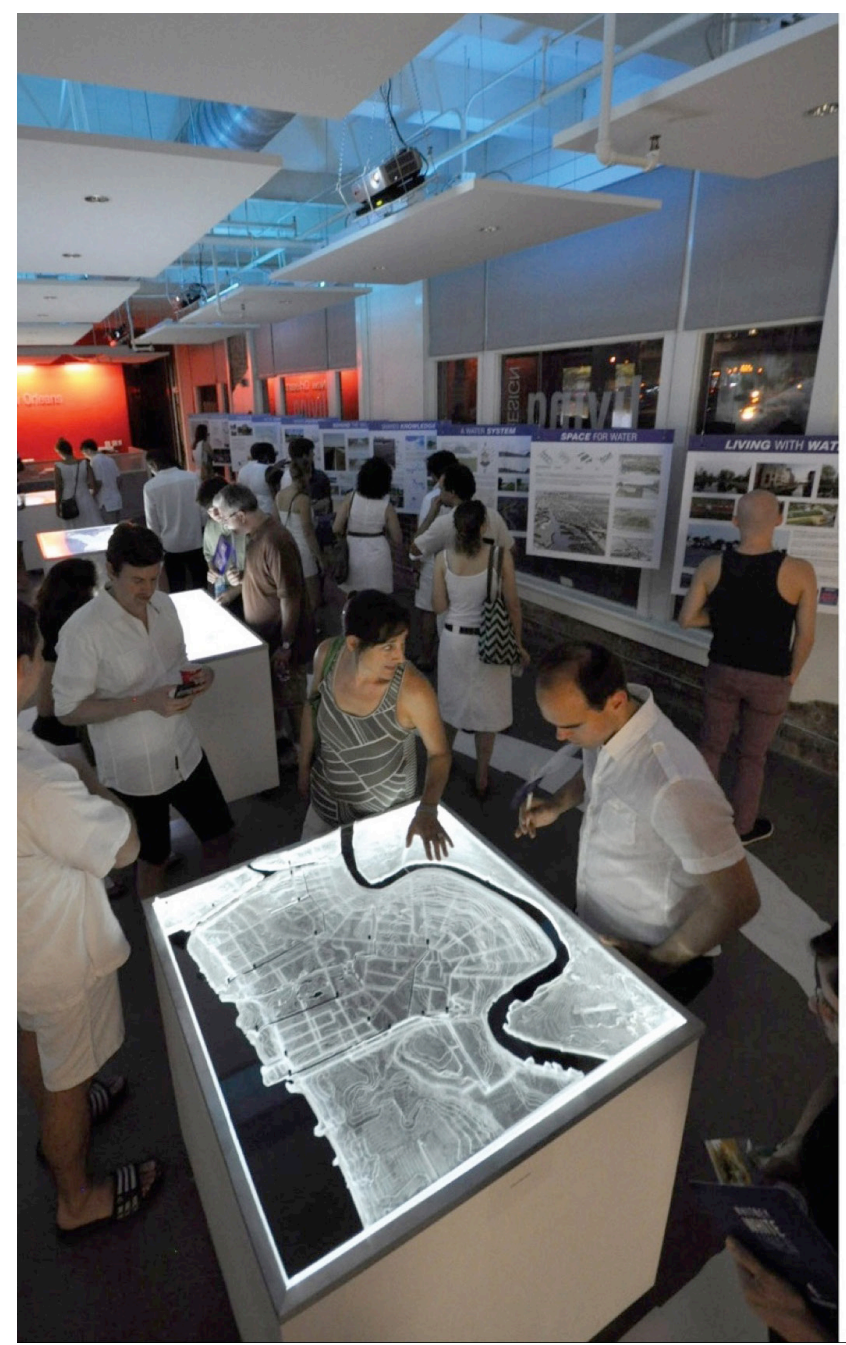

Figure 3: Interactive model of New Orleans hydrology and hydraulics (credit: Gutter to Gulf/Hoeferlin/Shelley,/Wolff/University of Toronto/ Washington University in St. Louis).

freedom to put somewhat radical ideas on the table, ones that were based on the realities of the existing landscape (such as the above mentioned HSDRSS or the deteriorating existing drainage network run by the Sewerage \& Water Board).

\section{Gutter to Gulf:}

1) Is an international academic collaboration between two schools outside of New Orleans: Washington University in St. Louis Sam Fox School of Design \& Visual Arts (led by architecture and urban design assistant professor Derek Hoeferlin) and University of Toronto Faculty of Architecture, Landscape, and Design (led by landscape architecture associate professor Jane Wolff and landscape architecture assistant professor Elise Shelley), with the three faculty members having strong ties to the New Orleans in different ways

2) Collaborates with New Orleans local groups such as Longue Vue House \& Gardens, Tulane University, Waggonner \& Ball Architects, New Orleans City Planning Association, and various neighborhood residents and organizations

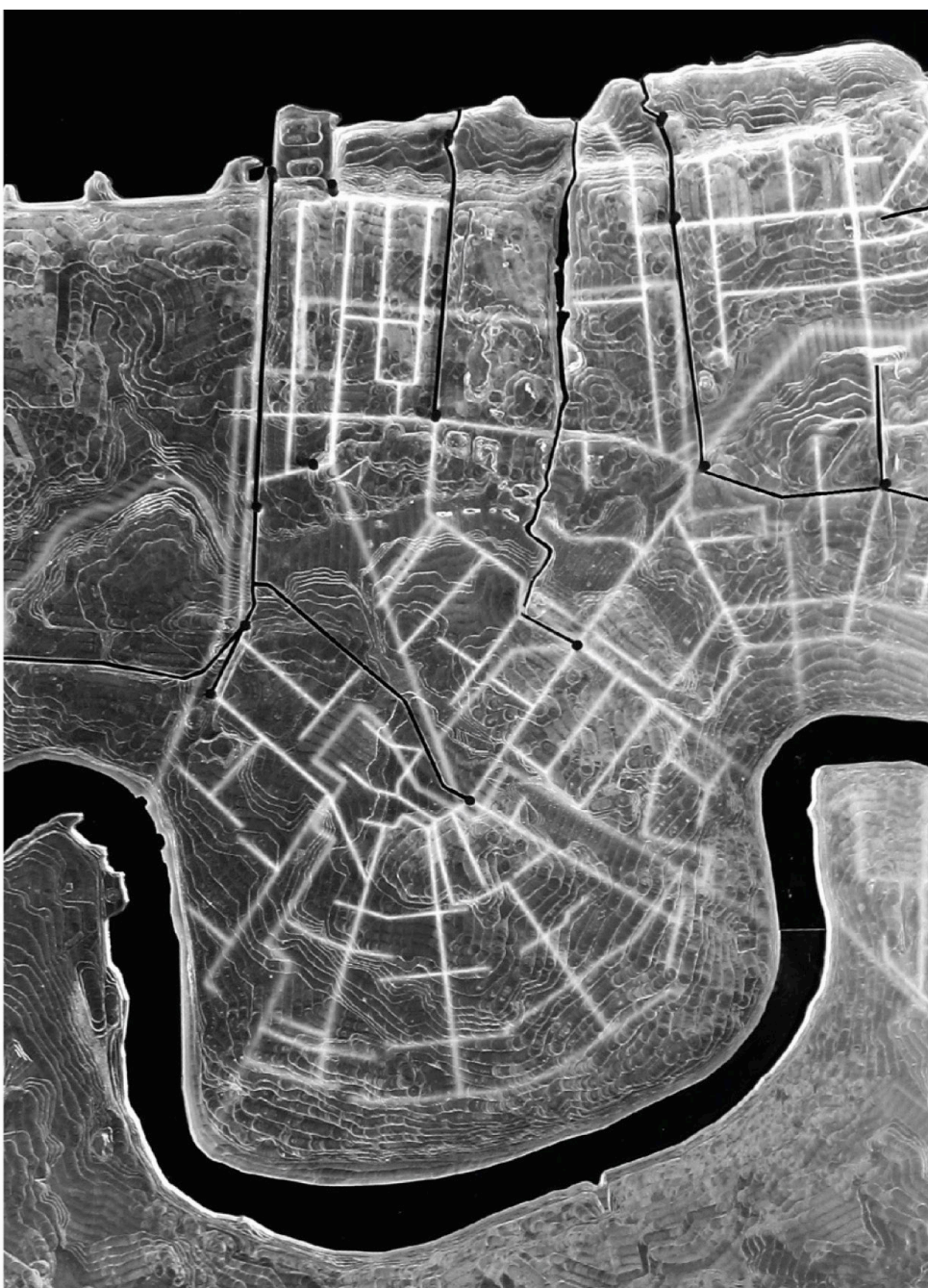

3) Informs-and acts independently of-Dutch Dialogues. In other words, in addition to retaining its own academic autonomy, Gutter to Gulf does not operate in an academic bubble. Rather, Gutter to Gulf has helped to provide base information to Dutch Dialogues, and vice versa. Remember, there was little to no funding at the time, so any post-Katrina effort that pulled upon academic labor for advocacy purposes, was more than welcome at the time, despite certain ethical questions that may have arisen.

Most striking about Dutch Dialogues and Gutter to Gulf is that each is incredibly pragmatic. Meaning, both do not concerned themselves with extraordinary problems, such as hurricanes per se, but rather, each sharply focuses on everyday issues of local stormwater management. Both initiatives are able to get the public ear by asking simple questions like: "do you want your car to keep flooding, or in heavier rain events, the first floor of your house to get wet?" In other words, both initiatives are able to make connections with communities for very practical reasons, not hyperbolic ones.

With gritty persistence over multiple years (Dutch Dialogues held 3 multi-disciplinary workshops and published a book of the results; Gutter to Gulf ran 4 design studios and created educational websites of the results), both greatly help to advocate for the need and 


\section{In New Orleans, the physical city and the policy city affect each other in profound ways.}

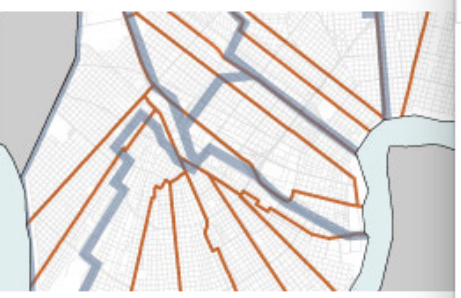

click image for interactive map

In New Orleans, the physical city and the policy has documented existing conditions in both are! upheld rigorous standards of documentation to multiple systems.

\section{Digital Models | Physical Models}

Understanding the city's current circumstances differences in topography have an enormous im affects permeability, and a giant network of pipe the status quo is unreliable, incomplete, and so

There has been little coordination of information terrain, its infrastructure, its building patterns, ar -for instance, its political subdivisions, its planr designated neighborhoods. However, considere knowladra of the nther

Figure 4: Above: Interactive website, page comparing incongruity of the physical and the policy city,; and, in this case, subsidence and planning districts (credit: Gutter to Gulf/Hoeferlin/Shelley,/Wolff/University of Toronto/ Washington University in St. Louis).
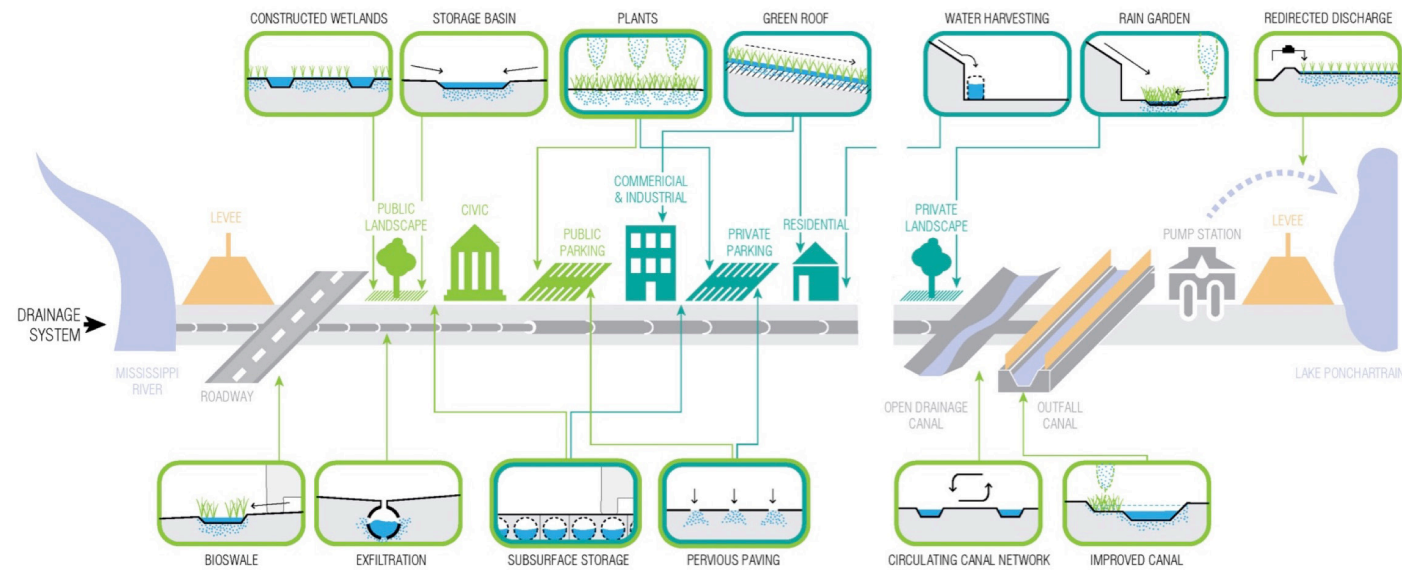

content.guttertogulf.com

\section{POLICY/PHYSICAL CITY}

Roll over or click on the thumbnails for more info.

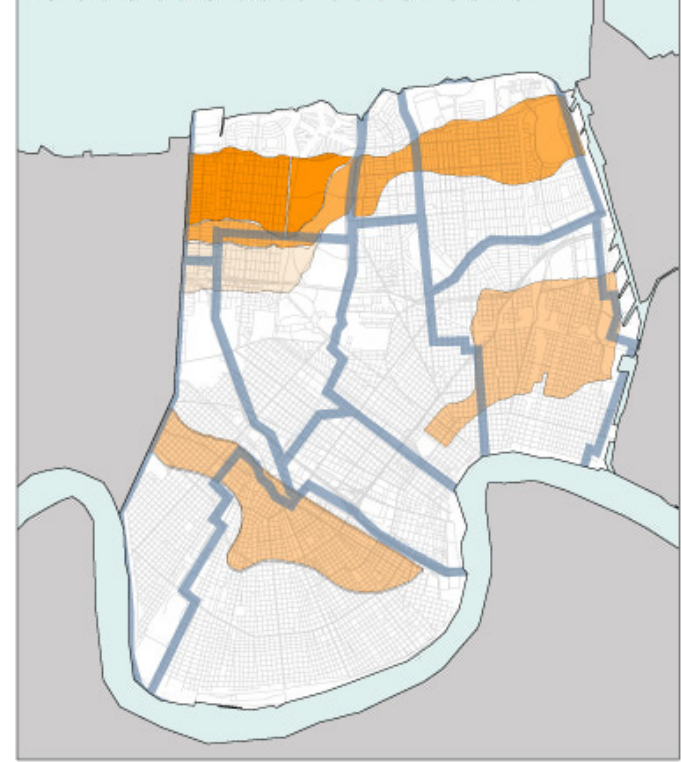

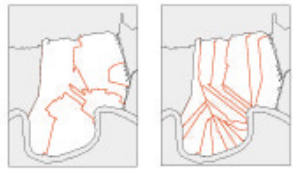
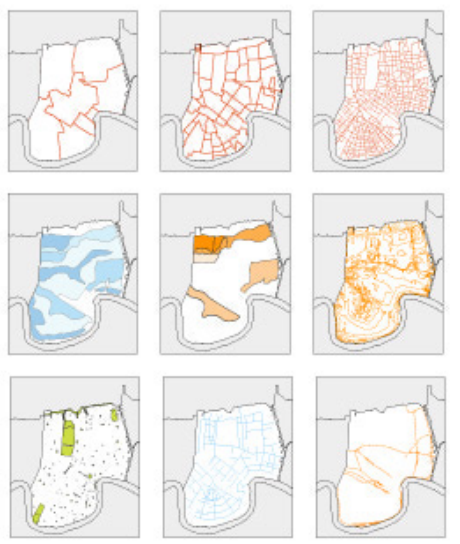

SUBSIDENCE
Figure 5: Below: Proposed Integrated Water Management System: Operations and Maintenance (credit: Greater New Orleans Inc./Waggonner \& Ball Architects).
PROPOSED INTEGRATED WATER MANAGEMENT SYSTEM Operations \& Maintenance

Flood Protection
(USACE \& SLFA-E)

Existing Grey Infrastructure (Orainage Authorities, Public Works Public Blue-Green Infrastructure (Drainage Authorities, Public Works,
Parks \& Green Spaces) Private Blue-Green Infrastructure (Private Property Owners) 
the commission of the Greater New Orleans Urban Water Plan. From the Greater New Orleans Water Plan website: “In 2010, the State of Louisiana's Office of Community Development - Disaster Recovery Unit funded Greater New Orleans, Inc. (GNO, Inc.) to develop the Greater New Orleans Urban Water Plan for the east banks of Orleans and Jefferson Parishes and St. Bernard Parish using federal Community Development Block Grant - Disaster Recovery funds from the Department of Housing and Urban Development. New Orleans firm Waggonner and Ball led a team of local and international water management experts in developing the Urban Water Plan."

What is most striking about the above quote is the structure of the parties involved.

1) The funding mechanism is pretty straightforward: it came from the Federal level (US Housing and Urban Development), funneled through the State (through post-Katrina facilitator of funding allocations, LA Disaster Recovery Unit).

2) The design team is relatively innovative since it continues the Dutch-American collaboration, led by local firm Waggonner \& Ball, but there is nothing new about international consortiums.

3) The client is what is most striking: Greater New Orleans, Inc. (GNO, Inc.) is basically the local Chamber of Commerce. In other words, the water plan is in no way a jurisdictionally endorsed plan. One could argue it is intentionally not endorsable, so as to retain its own autonomy as a living document and plan designed to enable other partnerships. In fact, the plan is a long-term economic development strategy, built around the advocacy efforts that prioritize water as the key design tool and metric for the future of New Orleans development, under the mantra "Living with Water." As such, GNO, Inc. has been able to broker public-private partnerships for pilot projects across the city, such as the Mirabaeu property, a 25-acre parcel owned by the Congregation of St. Joseph nuns. Such a large, single-owned parcel is a rarity within the city. From the website: "Stormwater storage and filtration, environmental education, and athletic fields can support the community and educational programming. A system of wetland terraces, rain gardens, bioswales, and a woodland wash provide diverse habitats for native flora and fauna. The site can become a model for lowland water management." In short, the innovative structure of the GNO Water Plan has allowed it to engage other emerging models of development, and ones most recently aligned with themes of resiliency planning. The GNO Water Plan is a centerpiece project for the city's Resiliency Plan as part of the Rockefeller Foundation 100 Resilient Cities Initiative. Most recently, the city was awarded a \$141 million USD grant from the US Housing \& Urban Development National Disaster Resilience Competition (NDRC) to fund the Gentilly Resiliency District, which is one of the water-infrastructure plans from the GNO Water Plan.

\section{CONCLUSION: THE BIG ELEPHANT IN THE ROOM: PROCUREMENT FUNDING}

But here is the trick to solve. Despite the new public-private funding mechanisms listed above, they rely heaving on foundational support groups, such as the Rockefeller Foundation. Innovative, integrated design hits a big roadblock when it comes up against current United States funding mechanisms, ones that are stuck in the mud, in a 20th century model of funding streams. Current procurement funding practices still operate in a series of silos. Just as many have argued (including the author) that the design disciplines still tend to operate safely, and therefor negatively, within each of their own silos, more disconcerting is that the same holds true for massive funding mechanisms. In other words, if we, as designers, propose a "bundled infrastructure design," one that integrates transportation, flood protection, social service programs, etc., it is extremely challenging to bundle the funding sources. I am no economist, but it is clear that there is no one-stop shop for "integrated design funding." Billions of dollars are out there, and are being allocated for projects. But the funded projects tend to be single-minded in scope. They fund just a highway. They fund just a school. They fund just a floodwall. (Case and point: the \$14.5 billion USD Hurricane \& Storm Damage Risk Reduction System). But until we are able to Design a New Funding Source for Integrated Design, resiliency planning will continue to struggle to get off the ground in the United States, thereby hindering its ability to integrate across the Americas. And cynically be regarded as just a trend or worse, as planner speak buzzwords.

\section{ACKNOWLEDGEMENTS}

I would like to thank my colleagues I have closely worked with since Hurricane Katrina on the projects highlighted in this paper. Specifically: architect David Waggonner, FAIA, along with his firm Waggonner \& Ball Architects; associate professor of landscape architecture Jane Wolff and assistant professor of landscape architecture Elise Shelley and their students at University of Toronto; senior economist Dale Morris of the Royal Netherlands Embassy, Washington D.C.; my Dutch colleagues, particularly Stijn Koole, Robbert de Koning, Han Meyer, and Steven Slabbers; and, most importantly, my dozens of Gutter to Gulf students at Washington University in St. Louis.

\section{ENDNOTES}

1. See: http://www.mvn.usace.army.mil/Portals/56/docs/HSDRRS/TFH\%20FF\%20 Brochure\%2027\%20May\%202016\%20\%20Final.pdf

2. See: http://coastal.la.gov/a-common-vision/2012-coastal-master-plan/

3. See http://dutchdialogues.com

4. See http://guttertogulf.com

5. See http://livingwithwater.com/blog/urban_water_plan/about/

6. See: http://livingwithwater.com/blog/urban_water_plan/plan/urbandesign/ lafitte-to-lakefront/\#jp-carousel-3970 